\title{
Genetic Influence on Chemical Constituents of Tobacco Leaf and Smoke*
}

\author{
by James $F$. Chaplin \\ Tobacco Research Laboratory, Agricultural Research Seroice, \\ U.S. Department of Agriculture, Oxford, North Carolina, U.S.A. \\ and
}

Department of Crop Science, North Carolina State University, Raleigh, N. C., U.S.A.

Tobacco (Nicotiana tabacum L.) is unique among agricultural crops in the United States in that about $90 \%$ of the commercially important part of the plant, the leaf, is consumed in the form of smoke. Therefore, the chemical composition of the leaf and smoke are important to the consumer. Tobacco smoke contains many different chemical compounds, their presence and relative concentrations depend upon composition of the tobacco leaf, additives, and manufacturing processes. However, the most important factor is the tobacco leaf itself. Although flavoring and other additives are applied in varying amounts by the manufacturer, the tobacco gives the flavor, aroma, and chemical constituents that make the smoke desirable and pleasing to the consumer.

Chemical constituents in the tobacco leaf are influenced by many factors as the tobacco plant develops from seed to the cured leaf. These factors include genetic potential, environmental conditions, cultural practices, and curing methods. Interactions among the factors also influence the chemical composition of the cured leaf. The genetic makeup of the plant provides the potential to produce or not produce certain compounds, the realization of these potentials depend on environmental variations such as cultural, curing, and processing conditions.

Most of the early breeding work in tobacco was directed toward disease resistance, yield, and other agronomic characters. Not until recently have geneticists begun to explore the possibility of altexing certain physical and demical characteristics of the tobacco leaf by breeding [Mann et al. (1), and Legg and Collins (2)].

The five major products manufactured from tobacco leaves are cigarettes, pipe tobacco, cigars, chewing tobacco, and snuff. Different tobaccos have been developed for each of these uses and are rarely interchangeable. The two classes of tobacco grown in the United States used mainly in cigarettes are [1] flue-cured or bright tobacco and [2] air-cured which consists of burley and Maryland. Cigarettes also may contain a small amount of imported Oriental tobacco. Considerable differences in the chemical composition of the cured

\footnotetext{
- Presented at the 169th American Chemical Society Meeting, Philadel-
} phia, Pa., U.S.A., 1975. leaf of these classes are due to variations in heredity, environment, cultural practices and curing methods.

Two genes at the $y b$ loci are the major differences in genetic composition between burley and flue-cured tobacco. Two recessive genes at these loci causes burley to have a lower dilorophyll content than fluecured tobacco. Chemically, burley tobacco is characterized by low reducing sugars, high nicotine, and high nitrate nitrogen levels, whereas flue-cured tobacco is characterized by high reducing sugar and moderate nicotine levels, besides certain flavor and aroma characteristics that are considered desirable in cigarette production. The Maryland type, used in small quantities in some cigarette blends, is characterized by low ricotine and good fire-holding capacity or burning quality. Some investigations have been conducted to determine if the differences in demical constituents among these tobaccos are due to the genetic makeup of the cultivars or to the environmental variations which they are subjected to.

Although some researchers have studied the mode of inheritance of certain chemical compounds, except for nicotine, very few have been reported to date. Variations in other chemical constituents among cultivars and breeding lines have been observed and reported. When environmental and cultural conditions are constant and strain differences are found for a constituent, one can assume that these differences are genetic. Information presented in this paper indicates that variations based on genetic differences for certain levels of chemical constituents exist.

\section{NICOTINE}

Nicotine, probably the most important constituent in tobacco, is the substance that makes the plant unique. Few other plants outside the genus Nicotiana produce nicotine. There are about 65 species in the genus Nicotiana but only two, N. tabacum and N. rustica, synthesize appreciable amounts of nicotine. Since nicotine is so important, naturally it is the most intensively studied themical constituent in tobacco.

At least two genetic systems regulate the production 
Table 1. Average level of alkalolds of the nine genotypes over two locatlone (7).

\begin{tabular}{llllll} 
& BB & Bb & bb & Mean \\
\cline { 2 - 5 } & \multicolumn{5}{l}{ (percent total alkaloids) } \\
AA & $4.58^{*}$ & 4.24 & $4.20 *$ & 4.34 \\
$\mathrm{Aa}$ & 3.96 & 3.48 & 3.04 & 3.49 \\
$\mathrm{aa}$ & $2.54^{*}$ & 1.48 & $0.30^{*}$ & 1.44 \\
\hline Mean & 3.69 & 3.07 & 2.51 & \\
\hline
\end{tabular}

- The genetically stable genotypes.

and levels of nicotine in the leaf of the tobacco plant. One system controls the ability to convert nicotine to nornicotine, and the other system controls total alkaloid levels. Most cultivars of commercial tobacco produce and retain nicotine as their primary alkaloid. However, except for $N$. rustica, most of the other Nicotiana species have nornicotine as the principal alkaloid. Nornicotine is produced by demethylation of nicotine to nornicotine (3). Although there are two potential loci for nicotine conversion in commercial cultivars of tobacco, only one of these, the $C_{1}$ locus, appears to account for alkaloid conversion in nornicotine-producing tobaccos $(4,5)$. Occasionally, individual plants are observed with high amounts of nornicotine in normal nonconverting cultivars.

Two major genes determine the base levels of total alkaloids in tobacco cultivars, however, these levels are further modified by minor genes or quantitative factors. The major genes were described by Legg et al. (6) and Legg and Collins (7). They postulated that two loci in burley and flue-cured tobacco regulate major levels of total alkaloids (predominately nicotine) and have produced burley lines homozygous for four levels (Table 1). It has been assumed that most commercial cultivars of burley and flue-cured tobacco have two dominant genes (AABB) for alkaloid levels. However, cultivars of tobacco have been produced with smaller differences in total alkaloids. Therefore, levels among the commercial cultivars appear to be controlled by quantitative genes in much the same manner as yield and other agronomic traits. Matzinger et al. (8) reported that nicotine content in flue-cured tobacco hybrids was intermediate between the two parents and that most of the genetic variation was additive.

Flue-cured and burley cultivars and breeding lines have been produced with varying levels of nicotine. Fluecured cultivars representing the relative range in nicotine levels are: high 4.76\%, SC 58; mid 3.31\%, NC 95; and low $1.81 \%$, Coker 139 (9). In addition, LAFC 53 (10) was recently released as a breeding line with a total alkaloid level of only $0.20 \%$. Furthermore, Chaplin and Burk (9) reported to distinct levels of total alkaloids in breeding lines produced by the haploid/diploid method. These ranged from $0.14 \%$ to as high as $4.00 \%$ total alkaloids with nicotine as the predominant alkaloid. Total nicotine levels are genetically controlled, but they are also influenced considerably by cultural practices, fertilizer applications, time of topping, and amount of rainfall. Despite the apparent complexity of these systems of inheritance, the position or rank of one cultivar relative to other cultivars remains constant over a wide range of environments. The presence of high levels of nornicotine in tobacco leaves tends to give an undesirable taste to smoke produced from them. Nornicotine in the cured leaf should not comprise more than $0.8 \%$ of the total alkaloids.

\section{NITROGENOUS COMPOUNDS OTHER THAN NICOTINE}

Tobacco leaves high in total nitrogen produce a strong, pungent-tasting smoke and those low in nitrogen produce a flat, insipid-tasting smoke. Collins et al. (1I) analyzed tobacco leaves from six flue-cured cultivars for certain chemical constituents including total nitrogen, soluble nitrogen, alpha amino nitrogen and total volatile bases (TVB). They found that each of these constituents varied among the cultivars evaluated. Total nitrogen ranged from $1.84 \%$ to $2.23 \%$, amount of the total nitrogen that was soluble from $52.28 \%$ to $61.64 \%$, alpha amino nitrogen from $0.151 \%$ to $0.197 \%$ and TVB from $0.233 \%$ to $0.507 \%$ (Table 2).

Table 2. Nitrogenous compounds of six flue-cured tobacco cultivars over five locations for 3 years (11).

\begin{tabular}{|c|c|c|c|c|c|}
\hline Cultivar & $\begin{array}{c}\text { Total } \\
\text { nitrogen } \\
(\%)\end{array}$ & $\begin{array}{l}\% \text { of total } \\
\text { nitrogen } \\
\text { (soluble) }\end{array}$ & $\begin{array}{c}\text { Alpha amino } \\
\text { nitrogen } \\
(\% / 0)\end{array}$ & $\begin{array}{c}\text { Total volatile } \\
\text { bases* } \\
(\%)\end{array}$ & $\begin{array}{c}\text { Total volatile } \\
\text { bases minus } \\
\text { nicotine } \\
(\%)\end{array}$ \\
\hline Dixie Bright 101 & 1.98 & 56.50 & 0.152 & 0.341 & 0.109 \\
\hline 402 & 2.16 & 60.17 & 0.197 & 0.437 & 0.118 \\
\hline Coker 139 & 1.84 & 52.58 & 0.151 & 0.233 & 0.095 \\
\hline Dixie Bright 244 & 2.00 & 56.48 & 0.166 & 0.304 & 0.115 \\
\hline Hicks & 2.00 & 59.03 & 0.163 & 0.374 & 0.102 \\
\hline Oxford 1-181 & 2.23 & 61.64 & 0.180 & 0.507 & 0.120 \\
\hline Cultivar LSD $: 0.05$ & 0.16 & 2.96 & 0.043 & 0.033 & 0.017 \\
\hline$: 0.01$ & 0.21 & 3.97 & NS** & 0.045 & NS \\
\hline Coefficient of variation $(\%)$ & 8 & 4 & 16 & 10 & 16 \\
\hline
\end{tabular}

- Total volatile bases as $\mathrm{NH}_{3}$.

** NS: Entries not different at $5 \%$ level of probability.
+ LSD: Least significant difference. Any two means whose difference exceeds this value are significantly different at the .05 or .01 probability level. 
Table 3. Nitrogen constituents among cultivars of fluecured tobacco (28).

\begin{tabular}{|c|c|c|c|c|}
\hline Cultivar & $\begin{array}{c}\text { Total } \\
\text { alkaloids } \\
(\%)\end{array}$ & $\begin{array}{c}\text { Total } \\
\text { nitrogen } \\
(\%)\end{array}$ & $\begin{array}{c}\text { Ammonia } \\
\text { nitrogen } \\
\text { (ppm) }\end{array}$ & $\begin{array}{c}\text { Total } \\
\text { volatile } \\
\text { bases } \\
(\%)\end{array}$ \\
\hline SC 58 & 3.58 & 3.12 & 0.063 & 0.688 \\
\hline NC 95 & 2.87 & 2.87 & 0.045 & 0.542 \\
\hline Coker 139 & 1.37 & 2.49 & 0.036 & 0.398 \\
\hline LN 38 & 0.10 & 2.35 & 0.041 & 0.292 \\
\hline Cultivar LSD*: 0.05 & 0.28 & 0.14 & 0.005 & 0.083 \\
\hline$: 0.01$ & 0.40 & 0.20 & 0.007 & 0.153 \\
\hline
\end{tabular}

- LSD: Least significant difference. Any two means whose difference exceeds this value are significantly different at the .05 or .01 probabllity level.

In another study, four flue-cured cultivars of tobacco were analyzed for total alkaloids, total nitrogen, ammonia nitrogen, and TVB (26). The range was as follows: total nitrogen from $2.35 \%$ in $\mathrm{LN}_{38}$ to $3.12 \%$ in SC 58, ammonia nitrogen from $0.036 \mathrm{ppm}$ in Coker $139^{*}$ to $0.063 \mathrm{ppm}$ in SC 58 , and total volatile bases from $0.292 \%$ in LN 38 to $0.688 \%$ in SC 58 (Table 3).

Collins et al. (12) also determined nitrogen conterit in four burley breeding lines differing in total alkaloid content. Differences existed for total nitrogen, nitrate nitrogen, protein nitrogen and total volatile bases. Total nitrogen and total volatile bases were higher in the higher-alkaloid lines, but nitrate nitrogen and protein nitrogen were higher in lower alkaloid lines.

Chaplin (13) studied total nitrogen, percentage of soluble nitrogen, and alpha amino nitrogen in leaves from eight flue-cured cultivars and their hybrids. He concluded that there was genetic variation for each of the constituents and that most of this variation resulted from additive gene action.

All these data indicate that variations for certain nitrogenous compounds exist among cultivars and that levels may be altered by breeding. Accordingly, in an effort to maintain quality in flue-cured tobacco, nitrogen levels have been established in a minimum standards program. To qualify for release a new cultivar must have, in addition to certain nicotine and reducing sugar levels, certain levels of total nitrogen, alpha amino nitrogen, and insoluble nitrogen. These chemical constituents of potential cultivars are kept within established limits by breeding and selection.

\section{PHENOLIC COMPOUNDS}

Tso (14) reported total phenolics differed between two cultivars of flue-cured tobacco. Total phenolics ranged from $0.5 \%$ in Hicks Broadleaf to $1.4 \%$ in Coker 139 (Table 4). Sheen and Calvert (15) showed differences in air-cured leaf for percentage of polyphenols among several tobacco lines. In the air-cured leaf, they found that the flue-cured cultivars Hicks and 402 had higher chlorogenic acid content than the air-cured types such as burley and Turkish. Sheen has selected a line of burley tobacco which is lower in polyphenols than current commercial cultivars.

Small variations in polyphenol content of flue-cured cultivars were reported by Anderson et al. (16) and these data are presented (Table 5). Penn and Weybrew (17) found that curing methods were much more important to chlorogenic acid content than types. Traditionally grown burley contains much less dhlorogenic acid than normally grown flue-cured. However, only minor differences were noted between the two classes when they had been cultured and cured under the same conditions.

Table 4. Chemical constituenis in the leaf and smoke of flue-cured tobacco cultivars (14).

\begin{tabular}{l|c|c|c|c|c}
\hline \multirow{2}{*}{ Cultivar } & \multicolumn{3}{|c|}{ Leaf constituents } & \multicolumn{2}{c}{ Smoke constituents } \\
\cline { 2 - 7 } & $\begin{array}{c}\text { Nico- } \\
\text { tine } \\
(\%)\end{array}$ & $\begin{array}{c}\text { Total } \\
\text { pheno- } \\
\text { lics } \\
(\%)\end{array}$ & $\begin{array}{c}\text { Total } \\
\text { sterols } \\
(\mathrm{mg} / \mathrm{g})\end{array}$ & $\begin{array}{c}\text { Total } \\
\text { parti- } \\
\text { culate } \\
\text { matter } \\
(\text { TPM) } \\
(\mathrm{mg} / \mathrm{cgt})\end{array}$ & $\begin{array}{c}\text { TPM/ } \\
\text { puff } \\
(\mathrm{mg} / \\
\text { puff) }\end{array}$ \\
\hline Coker 139 & 1.5 & 1.4 & 1.97 & 27 & 3.3 \\
PD 33 & 1.6 & $-* *$ & - & 28 & 3.4 \\
Hicks Broadleaf & 2.7 & 0.5 & 1.38 & 33 & 4.1 \\
NC 402 & 2.9 & - & - & 29 & 3.7 \\
NC 95 & 2.9 & - & - & 30 & 4.0 \\
SC 58 & 3.4 & - & - & 34 & 4.3 \\
\hline
\end{tabular}

- Includes water.

" Not tested.

Table 5. Soluble plant phenols In flue-cured tobacco cultivars grown with three rates of fertilizer averaged over the three rates (16).

\begin{tabular}{l|c}
\hline \multicolumn{1}{c|}{ Cultivar } & $\begin{array}{c}\text { Total soluble plant phenols, } \\
\text { chlorogenic acid equivalent } \\
(\%)\end{array}$ \\
\hline Coker 319 & 5.42 \\
Va. 115 & 5.40 \\
NC 95 & 5.61 \\
McNair 12 & 5.27 \\
Speight G-7 & 5.34 \\
Hicks Broadieaf & 6.23 \\
NC 2326 & 5.74 \\
McNair 30 & 6.04 \\
Reams 266 & 5.45 \\
Golden Wilt & 5.43 \\
\hline Cultivar LSD*: 0.05 & 0.63 \\
\hline LSD: Least significant difference. Any two means whose difference \\
exceeds this value are slgniflcantly different at the .05 probability \\
level.
\end{tabular}

\section{REDUCING SUGARS}

The level of reducing sugars is very important in determining the quality of flue-cured tobacco. A certain level is required for the tobacco to be acceptable and usable in cigarette blends. Very little reducing sugars are in the cured leaf of any of the air-cured types. Tests 
Table 6. The effecte of cultural and curing practices on the reducing sugar contente of burley and flue-cured tobaccos (17).

\begin{tabular}{|c|c|c|c|c|c|}
\hline \multirow{2}{*}{ Type } & \multirow{2}{*}{$\begin{array}{l}\text { Cultured: } \\
\text { Cured: }\end{array}$} & \multicolumn{2}{|c|}{ Flue-cured } & \multicolumn{2}{|c|}{ Burley } \\
\hline & & Flue & Air & Flue & Air \\
\hline \multicolumn{2}{|l|}{ "C" Priming } & \multicolumn{4}{|c|}{$(\%$ reducing sugar, dry basis } \\
\hline \multirow{2}{*}{\multicolumn{2}{|c|}{$\begin{array}{l}\text { Flue-cured, " } 402 " \\
\text { Burley, "Ky } 16 "\end{array}$}} & 31.6 & 18.7 & 9.7 & 14.3 \\
\hline & & 13.1 & 6.5 & 5.2 & 5.2 \\
\hline \multicolumn{6}{|c|}{ “F“ Priming } \\
\hline \multirow{2}{*}{\multicolumn{2}{|c|}{$\begin{array}{l}\text { Flue-cured, "402" } \\
\text { Burley, "Ky 16" }\end{array}$}} & 32.6 & 15.9 & $-*$ & - \\
\hline & & 10.1 & 5.5 & - & - \\
\hline
\end{tabular}

- Not tested.

conducted by Penn and Weybrew (17) showed that some of the difference in sugar content between burley and flue-cured tobacco is due to cultural and growing conditions. However, genetic factors also contributed to observed differences (Table 6).

Flue-cured cultivars vary in reducing sugar levels. Collins et al. (11) showed that reducing sugar levels ranged from $11.76 \%$ to $16.67 \%$ among six flue-cured cultivars. Studying an eight-cultivar diallel, Chaplin (13) showed that genetic variation for levels of reducing sugars existed among cultivars of flue-cured tobacco and that the genetic variance resulted from additive gene action.

\section{PHYTOSTEROLS}

Davis et al. (18) reported that phytosterol content varied from approximately 1.49 to $2.10 \mathrm{mg} / \mathrm{g} \mathrm{dry}$ weight among six cultivars of burley tobacco (Table 7). The range was about $25 \%$ lower than that reported for flue-cured cultivars, but at that time it was not clear whether the differences between the burley and fluecured tobacco were due to genetic factors or to cultural and curing practices. A phytosterol range from $0.172 \%$ to $0.313 \%$ for 10 flue-cured cultivars was found by Cheng et al. (19) (Table 8). Cheng et al. (20) later showed differences among four cultivars of flue-cured tobacco ranging from $0.27 \%$ to $0.35 \%$ total phyto-

Table 7. Mean sterol levels in cultivars of burley tobacco (18).

\begin{tabular}{l|c|c}
\hline \multirow{2}{*}{ Cultivar } & \multicolumn{2}{c}{$\begin{array}{c}\text { 3-beta-hydroxysterols } \\
\text { (mg/g dry weight) }\end{array}$} \\
\cline { 2 - 3 } & Experiment A & Experiment B \\
\hline Ky Ex 42 & $1.54 \mathrm{a}^{*}$ & $1.53 \mathrm{a}^{*}$ \\
Ky 10 & $1.57 \mathrm{a}$ & $1.49 \mathrm{a}$ \\
Ky 16 & $1.77 \mathrm{~b}$ & - \\
Bu 2 & $1.89 \mathrm{~b}$ & - \\
Bu 21 & $1.91 \mathrm{~b}$ & $1.68 \mathrm{~b}$ \\
Ky 12 & $2.10 \mathrm{C}$ & $1.96 \mathrm{C}$ \\
\hline
\end{tabular}

- Letters differing from each other in a column differ signiflcantly at the $5 \%$ level by Duncan's Multiple Range Test.
Table 8. Sterols, yield, and total alkaloids of flue-cured tobacco cultivare (19).

\begin{tabular}{|c|c|c|c|}
\hline Cultivar & $\begin{array}{c}\text { Total } \\
\text { sterols } \\
(\%)\end{array}$ & $\begin{array}{c}\text { Yield } \\
\text { (lb./acre) }\end{array}$ & $\begin{array}{c}\text { Total } \\
\text { alkaloids } \\
(\%)\end{array}$ \\
\hline Coker 319 & 0.313 & 2,213 & 2.24 \\
\hline Va. 115 & 0.263 & 2,067 & 2.60 \\
\hline NC 95 & 0.259 & 2,331 & 2.72 \\
\hline McNair 12 & 0.251 & 2,194 & 2.62 \\
\hline Speight G-7 & 0.248 & 2,452 & 2.64 \\
\hline Hicks Broadleaf & 0.241 & 2,018 & 2.69 \\
\hline NC 2326 & 0.231 & 2,067 & 2.62 \\
\hline McNair 30 & 0.224 & 2,187 & 2.53 \\
\hline Reams 266 & 0.193 & 2,478 & 1.69 \\
\hline Golden Wilt & 0.172 & 1,750 & 2.75 \\
\hline Cultivar LSD*: 0.05 & 0.020 & 125 & 0.21 \\
\hline$: 0.01$ & 0.027 & 166 & 0.29 \\
\hline
\end{tabular}

* LSD: Least significant difference. Any two means whose difference exceeds this value are significantly different at the .05 or .01 probability level.

sterols. Significant differences among cultivars in both flue-cured and burley indicate that variations for phytosterol levels are genetically controlled within the two classes.

\section{ALKALINITY OF WATER-SOLUBLE ASH}

Alkalinity of water-soluble ash is mainly a measure, in the leaf tissue, of the potassium in combination with organic acids that form carbonates after ashing in a furnace. It reflects the burning characteristics of the leaf, a high value indicating freer burn. Flue-cured and burley tobaccos differ in their alkalinity of watersoluble ash. After transferring the burley character into flue-cured cultivars, Matzinger et al. (21) found that the difference in water-soluble ash between flue-cured and burley was controlled by gene loci other than $y b$ loci and that the differences were due to genetic factors rather than environment (Table 9). They also found that when a line with a low alkalinity number was crossed with one with a higher number, the low alkalinity number was dominant.

Table 9. Ash content and alkalinity number of watersoluble ash in lines with ybyyb1yb2yb2 genotypes (21).

\begin{tabular}{|c|c|c|}
\hline Entry & $\begin{array}{l}\text { Ash } \\
(\%)\end{array}$ & $\begin{array}{c}\text { Alkalinity } \\
\text { number of } \\
\text { water-soluble } \\
\text { ash }\end{array}$ \\
\hline Burley 21 & 21.40 & 50.6 \\
\hline Greenville $63-486$ & 20.26 & 69.0 \\
\hline yb SC 58 & 19.74 & 25.1 \\
\hline Burley $21 \times$ yb SC 58 & 20.10 & 18.0 \\
\hline Gr. $63-486 \times$ yb Sc 58 & 20.22 & 29.4 \\
\hline Cultivar LSD*: 0.05 & NS** & 10.2 \\
\hline$: 0.01$ & NS & 16.2 \\
\hline
\end{tabular}

- LSD: Least significant difference. Any two means whose difference exceeds this value are significantly different at the .05 or .01 probabillty level.

* NS: Entries not different at $5 \%$ level of probability. 
Table 10. Starch, cellulose, lignin, wax, crude ash, and alkalinity of the water-soluble ash (WSA) of four flue-cured tobacco cultivare In percentage oven-dry basis* (22).

\begin{tabular}{|c|c|c|c|c|c|c|c|}
\hline Cultivar & $\begin{array}{c}\text { Starch } \\
(\%)\end{array}$ & $\begin{array}{c}\text { Holo- } \\
\text { cellulose } \\
\text { (chlorite } \\
\text { method) } \\
(\%)\end{array}$ & $\begin{array}{c}\text { Holo- } \\
\text { cellulose } \\
\text { (Bacot } \\
\text { method) } \\
(\%)\end{array}$ & $\underset{(\%)}{\operatorname{Lignin}}$ & $\begin{array}{l}\text { Wax } \\
(\%) .\end{array}$ & $\begin{array}{c}\text { Crude ash } \\
(\%)\end{array}$ & $\begin{array}{l}\text { Alkalinity of } \\
\text { WSA }^{\star *}\end{array}$ \\
\hline SC 58 & 6.0 & 44.2 & 10.2 & 2.6 & 0.30 & 18.1 & 5.0 \\
\hline LN 38 & 6.4 & 41.7 & 11.2 & 3.2 & 0.30 & 18.9 & 6.5 \\
\hline Coker 139 & 5.4 & 35.8 & 12.6 & 3.2 & 0.36 & 19.5 & 7.2 \\
\hline NC 95 & 7.2 & 33.2 & 11.2 & 2.9 & 0.26 & 17.3 & 6.0 \\
\hline Cultivar LSD+: 0.05 & 0.3 & 2.3 & 0.8 & 0.2 & NS & 0.3 & 0.1 \\
\hline$: 0.01$ & 0.5 & 4.3 & 1.4 & 0.4 & NS & 0.6 & 0.2 \\
\hline
\end{tabular}

- All calculations on a dry-welght basls.

- $\mathrm{ml}$ of $\mathrm{N} / 10 \mathrm{HCl} / \mathrm{g}$ molsture-free tobacco.
+ LSD: Least signiflcant difference. Any two means whose difference exceeds this value are significantly different at the .05 or .01 probability level.

\section{OTHER CONSTITUENTS}

Although data are limited, available evidence suggests that levels of other chemical constituents in tobacco are under genetic control. Bowman et al. (22) showed differences among flue-cured cultivars for starch, cellulose, lignin, crude ash, and alkalinity of the watersoluble ash (Table 10). In addition, Collins et al. (11) analyzed six flue-cured cultivars for 46 chemical and physical characteristics plus three agronomic characteristics and found cultivar differences for 37 of these traits.

Research has demonstrated that levels of many of the chemical constituents in the tobacco leaf are under genetic control, with the final level of any constituent being influenced by an interaction of genetic, environmental, cultural, and curing factors. Geneticists prefer to study a single character or single constituent, yet in a living system these compounds are interdependent. In many instances, if one chemical constituent is changed, another may also be changed. Then, too, if certain agronomic or disease resistant characteristics are changed, the chemistry of the tobacco plant may also be altered.

\section{SMOKE CONSTITUENTS}

Characteristics of tobacco smoke are largely a function of the chemical and physical properties of the leaf.

Table 11. "Means and ranges of 160 familles from a fluecured tobacco synthetle population (23).

\begin{tabular}{l|r|r|r}
\hline Character & Mean & $\begin{array}{c}\text { Low } \\
\text { family }\end{array}$ & $\begin{array}{c}\text { High } \\
\text { family }\end{array}$ \\
\hline Cigarette weight (g) & 0.93 & 0.67 & 1.23 \\
Alkaloids (mg/cgt.) & 31.71 & 18.22 & 46.79 \\
Puffs/cigarette & 9.02 & 6.33 & 14.42 \\
WTPM* (mg/cgt.) & 30.97 & 25.16 & 36.55 \\
WTPM (mg/puff) & 3.58 & 1.91 & 4.94 \\
\hline
\end{tabular}

* wot total particulate matter.
Although limited in number, some studies have shown genetic influence on certain smoke constituents.

Total particulate matter (TPM) represents the materials trapped on a standard Cambridge filter pad after the cigarette has been smoked under specified conditions. Tar is the weight of TPM minus nicotine and water. Matzinger and Wernsman (23) studied certain smoke constituents in a synthetic population of eight commercial cultivars of flue-cured tobacco. They showed significant genetic variations for cigarette weight, total alkaloids, puff/cigarette, WTPM/cigarette, and WTPM/ puff. WTPM* ranged from 25.16 to $36.55 \mathrm{mg} /$ cigarette (Table 11). They concluded from this experiment that changes in TPM could be accomplished thru breeding. Tso (14) reported a range of TPM from $26 \mathrm{mg} / \mathrm{g}$ tobacco smoked for Coker 139 to $33 \mathrm{mg}$ for SC 58 (Table 4). Chaplin (24) compared Maryland with flue-cured tobacco cultivars when both were air- and flue-cured and found that the Maryland cultivar had lower TPM per cigarette, whether air- or flue-cured, than did comparably cured flue-cured cultivars. However, TPM per puff did not differ among the cultivars. Also, in the Maryland tobacco when either air- or flue-cured, the nicotine and puff count per cigarette were lower (Table 12).

Rathkamp et al. (25) analyzed mainstream smoke from four flue-cured cultivars by stalk positions for selected toxic agents. Their results showed differences among stalk positions for all cultivars. When averaged over all stalk positions the data also revealed differences for certain constituents among the four cultivars. Among these were puff/cigarette, TPM, nicotine, TPM minus nicotine, $\mathrm{CO}, \mathrm{CO}_{2}$, acetaldehyde, acrolein, hydrogen cyanide in the gas phase and in the particulate phase, phenols, benzo(a)pyrene [BaP], and benz(a)anthracene [BaA] (Tables 13, 14, 15, and 16). In smoke produced from leaves from different cultivars certain constituents vary, thus these constituents might be changeable by breeding.

The prerequisite for the genetic change of the levels of a chemical constituent of tobacco or its smoke is heritable variation within tobacco or among its close relatives. This variation exists for many chemical 
Table 12. Smoke analyses of tobacco cultivars NC 2326, Coker 319, and Md. 609 when flue- and alr-cured (24).

\begin{tabular}{|c|c|c|c|c|c|c|c|}
\hline \multirow{2}{*}{ Curing method } & \multirow{2}{*}{ Cultivar } & \multicolumn{2}{|c|}{ Total particulate matter } & \multicolumn{2}{|c|}{ Nicotine } & \multirow{2}{*}{$\begin{array}{c}\mathrm{H}_{2} \mathrm{O} \\
\text { (mg/cgt.) }\end{array}$} & \multirow{2}{*}{$\begin{array}{c}\text { Puff } \\
\text { count/ } \\
\text { cigarette }\end{array}$} \\
\hline & & (mg/cgt.) & (mg/puff) & (mg/cgt.) & (mg/puff) & & \\
\hline \multirow[t]{3}{*}{ Flue-cured } & NC 2326 & 38.6 & 2.6 & 2.97 & 0.20 & 3.0 & 14.7 \\
\hline & Coker 319 & 36.8 & 2.6 & 2.80 & 0.20 & 3.0 & 14.1 \\
\hline & Md. 609 & 32.1 & 3.0 & 2.31 & 0.22 & 3.1 & 10.7 \\
\hline \multirow[t]{3}{*}{ Air-cured } & NC 2326 & 27.3 & 3.2 & 1.00 & 0.12 & 2.4 & 8.6 \\
\hline & Coker 319 & 26.6 & 3.4 & 0.89 & 0.12 & 2.4 & 7.8 \\
\hline & Md. 609 & 21.4 & 3.2 & 0.67 & 0.10 & 2.1 & 6.7 \\
\hline \multicolumn{2}{|c|}{$\begin{array}{l}\text { LSD* between cultivars for } \\
\text { same curing method } 0.05\end{array}$} & 3.6 & $N^{* *}$ & 0.44 & NS & NS & 0.6 \\
\hline \multicolumn{2}{|c|}{$\begin{array}{l}\text { LSD* between curing methods } \\
\text { for same cultivar } 0.05\end{array}$} & 6.1 & NS & 1.67 & NS & NS & 0.5 \\
\hline
\end{tabular}

- LSD: Least significant difference. Any two means whose difference exceeds this value are significantly different at the .05 probability level.

* NS: Entries not different at $5 \%$ level of probability.

Table 13. Analyses of clgarettes of four flue-cured cultivars averaged over elght stalk positions (25).

\begin{tabular}{l|c|c|c|c|c}
\hline Cultivar & $\begin{array}{c}\text { Average } \\
\text { weight/ } \\
\text { clgarette } \\
\text { (mg) }\end{array}$ & $\begin{array}{c}\text { Average } \\
\text { number } \\
\text { of puffs } \\
\text { (puft/cgt.) }\end{array}$ & $\begin{array}{c}\text { Total } \\
\text { parti- } \\
\text { culate } \\
\text { matter } \\
\text { (TPM) } \\
\text { (mg/cgt.) }\end{array}$ & $\begin{array}{c}\text { Nicotine } \\
\text { (mg/cgt.) }\end{array}$ & $\begin{array}{c}\text { TPM } \\
\text { minus } \\
\text { nicotine } \\
\text { (mg/cgt.) }\end{array}$ \\
\hline SC 58 & 1,076 & 10.0 & 38.30 & 4.23 & 34.07 \\
LN 38 & 1,031 & 8.7 & 28.37 & 0.37 & 28.00 \\
Coker 139 & 992 & 8.7 & 29.04 & 1.68 & 27.24 \\
NC 95 & 1,081 & 10.2 & 34.95 & 3.08 & 31.87 \\
\hline
\end{tabular}

Table 14. Carbon monoxide (CO) and carbon dioxide $\left(\mathrm{CO}_{2}\right)$ in cigarette mainstream smoke from four cultivars of flue-cured tobacco (averaged over eight stalk positions) (25).

\begin{tabular}{l|c|c}
\hline Cultivar & $\begin{array}{c}\text { CO } \\
\text { (mg/cgt.) }\end{array}$ & $\begin{array}{c}\text { CO2 } \\
\text { (mg/cgt. })\end{array}$ \\
\hline SC 58 & 20.1 & 65.2 \\
LN 38 & 18.9 & 60.1 \\
Coker 139 & 15.8 & 55.3 \\
NC 95 & 18.5 & 62.6 \\
\hline
\end{tabular}

Table 15. Analytical results of cigarettes made from elght stalk positions of four flue-cured cultivars (averaged over elght stalk positions) (25).

\begin{tabular}{|c|c|c|c|c|}
\hline \multirow[b]{2}{*}{ Cultivar } & \multirow[b]{2}{*}{$\begin{array}{c}\text { Acet- } \\
\text { aldehyde } \\
\text { ( } \mu \text { g/cgt.) }\end{array}$} & \multirow[b]{2}{*}{$\begin{array}{l}\text { Acrolein } \\
(\mu \mathrm{g} / \mathrm{cgt} .)\end{array}$} & \multicolumn{2}{|c|}{ Hydrogen cyanide } \\
\hline & & & $\begin{array}{c}\text { Gas phase } \\
(\mu \mathrm{g} / \mathrm{cgt} .)\end{array}$ & $\begin{array}{c}\text { Particulate } \\
\text { phase } \\
(\mu \mathrm{g} / \mathrm{cgt} \text { ) }\end{array}$ \\
\hline SC 58 & 977 & 82 & 336 & 179 \\
\hline LN 38 & 1,006 & 75 & 294 & 71 \\
\hline Coker 139 & 1,123 & 85 & 211 & 102 \\
\hline NC 95 & 1,015 & 82 & 260 & 172 \\
\hline
\end{tabular}

Table 16. Analytical results of clgarettes made from elght stalk positions of four flue-cured cultlvars (averaged over elght stalk positlons) (25).

\begin{tabular}{l|c|c|c}
\hline Cultivars & $\begin{array}{c}\text { Phenol } \\
(\mu \mathrm{g} / \mathrm{cgt} .)\end{array}$ & $\begin{array}{c}\text { BaP } \\
(\mathrm{ppm})\end{array}$ & $\begin{array}{c}\text { BaA } \\
(\mathrm{ppm})\end{array}$ \\
\hline SC 58 & 184.6 & 0.69 & 1.33 \\
LN 38 & 103.3 & 0.74 & 1.37 \\
Coker 139 & 117.6 & 0.73 & 1.39 \\
NC 95 & 168.7 & 0.80 & 1.60 \\
\hline
\end{tabular}

BaP: Benzo(a)pyrene.

BaA: Benz(a)anthracene.

ppm: part per million in dry TPM.

constituents. Some efforts have been made to deliberately change some of these; many more could probably be changed, if such changes are desired. However, breeding to change chemical constituents of the leaves of tobacco may be costly and time consuming. Chemists must play a major role in research in the area of genetic control of chemical constituents. Procedures for determining the amounts and importance of specific constituents in tobacco are needed. These techniques must be simple and inexpensive, so that they can be used for screening large numbers of plants. Chemists must also help more in planning and conducting experiments with the geneticist, to accomplish these goals. From present knowledge and experience, I believe that it is possible to alter the levels of most of the important constituents of tobacco by appropriate plant breeding methods.

\section{SUMMARY}

Investigations have shown that many chemical constituents in tobacco (Nicotiana tabacum L.) plants and in the cured leaf are influenced by genetic, environmental, and cultural factors. The genetic basis for 
nicotine synthesis is well documented and plant breeders are capable of developing cultivars with varying levels. Differences for chemical constituents have been detected among cultivars and breeding lines which are attributed to genetic factors. Some of these constituents are: reducing sugars, polyphenols, phytosterols, and nitrogenous compounds. Research also indicates that alkalinity of water-soluble ash and certain smoke constituents are influenced by genetic factors.

\section{ZUSAMMENFASSUNG}

Untersuchungen haben gezeigt, daB viele chemische Inhaltsstoffe der Tabakpflanze (Nicotiana tabacum L.) und des getrockneten Tabakblattes von genetischen, ökologischen und agronomischen Faktoren beeinflußt werden. Die genetische Grundlage der Nikotinsynthese ist gut belegt, und Pflanzenzühtern ist es möglich, Arten mit unterschiedlichen Gehalten zu ziehen. Zwischen Arten und Zuchtstämmen wurden Unterschiede in der chemischen Zusammensetzung beobaditet, die genetischen Faktoren zugeschrieben werden. Dabei handelt es sich um folgende Inhaltsstoffe: reduzierende Zucker, Polyphenole, Phytosterole und Stickstoffverbindungen. Forschungsarbeiten deuten darauf hin, daß die Basizität von wasserlöslicher Asche und bestimmte Rauchinhaltsstoffe von genetischen Faktoren beeinflußt werden.

\section{RESUME}

Des recherches ont montré que dans les plantes de tabac (Nicotiana tabacum L.) et dans les feuilles séchées, plusieurs composés himiques sont influencés par des facteurs génétiques, écologiques et de culture. On connaît bien les bases génétiques pour la synthèse de la nicotine, et les cultivateurs savent développer des variétés à différentes teneurs. Des différences en constitution dimique, détectées parmi certaines variétés et certaines lignées de descendance, ont été attribuées à des facteurs génétiques. Certains de ces constituants sont: des sucres réducteurs, des polyphénols, des phytostérols, et des composés nitrés. Des recherches indiquent également que l'alcalinité de la cendre soluble dans l'eau, et certains constituants de la fumée sont influencés par des facteurs génétiques.

\section{REFERENCES}

1. Mann, T. J., D. F. Matzinger and E. A. Wernsman: Genetic control of tobacco constituents; Symposium CORESTA/TCRC 1972, Williamsburg, Va., pp. 199 to 200.

2. Legg, P. D., and G. B. Collins: Influence of genetic factors on chemical composition of tobacco; Tobacco International 177, No. 2 (1975) 10-16.
3. Dawson, R. F.: Alkaloid biogenesis: Nicotine demethylation in excised leaves of Nicotiana glutinosa; Amer. J. Bot. 39 (1952) 250-253.

4. Mann, T. J., J. A. Weybrew, D. F. Matzinger and J. L. Hall: Inheritance of the conversion of nicotine to nornicotine in varieties of Nicotiana tabacum $L$. and related amphiploids; Crop Sci. 4 (1964) 349 to 353 .

5. Burk, L. G., and R. N. Jeffrey: A study of the inheritance of alkaloid quality in tobacco; Tob. Sci. 2 (1958) 139-141.

6. Legg, P. D., J. F. Chaplin and G. B. Collins: Inheritance of percent total alkaloids in Nicotiana tabacum L.; J. of Heredity 60 (1969) 213-217.

7. Legg, P. D., and G. B. Collins: Inheritance of percent total alkaloids in Nicotiana tabacum L., II: Genetic effects of two loci in Burley $21 \times$ LA Burley 21 populations; Canadian Journ. of Genetics and Cytology 13 (1971) 287-291.

8. Matzinger, D. F., T. J. Mann and C. C. Cockerham: Diallel crosses in Nicotiana tabacum; Crop Sci. 2 (1962) 383-386.

9. Chaplin, J. F., and I. G. Burk: Haploid/diploid method: A means of establishing tobacco breeding lines with different alkaloid levels; Symposium CORESTA/TCRC 1972, Williamsburg, Va., pp. $69-70$.

10. Chaplin, J. F.: Registration of LAFC 53 tobacco germplasm; Crop Sci. 15 (1975) 282.

11. Collins, W. K., G. L. Jones, J. A. Weybrew and D. F. Matzinger: Comparative chemical and physical composition of flue-cured tobacco varieties; Crop Sci. $x$ (1961) 407-411.

12. Collins, G. B., Paul D. Legg and C. C. Litton: Variation in nitrogenous constituents in four Nicotiana tabacum breeding lines differing in total alkaloid content; Agron. Abst. 1974 Annual Meetings, p. 65.

13. Chaplin, J. F.: Comparative performance of $F_{1}$ flue-cured tobacco hybrids and their parents, II: Chemical constituents; Tob. Sci. 11 (2967) 128-132.

14. Tso, T. C.: The effect of farm production practices on nicotine and total particulate matter in cigarette smoke; National Cancer Institute Monograph No. 28 (1968) 97-111.

15. Sheen, S. J., and J. Calvert: Quantitative variation in polyphenol content in the green and air-cured leaves of tobacco (Nicotiana tabacum L.); Tob. Sci. 13 (1969) 10-12.

16. Anderson, R. A., J. F. Chaplin, R. E. Currin and Z. T. Ford: Plant phenols in flue-cured tobacco fertilized at different rates; Agron. J. 62 (1970) 415-417.

17. Penn, P. T., and J. A. Weybrew: Some factors affecting the content of the principal polyphenols in tobacco leaves; Tob. Sci. 2 (1958) 68-72.

18. Davis, D. L., P. D. Legg and G. B. Collins: Distribution of total z-beta-hydroxysterols in burley tobacco; Crop Sci. to (1970) 545-547. 
19. Cheng, Amber L. 5., J. F. Chaplin and T. C. Tso: Sterol variation in flue-cured tobacco varieties; Tob. Sci. 12 (1968) 33-34.

2o. Cheng, Amber L. S., T. C. Tso and James F. Chaplin: Leaf characteristics of four flue-cured tobacco varieties according to stalk positions, 1 : Phytosterols and petroleum ether extracts; Crop Sci. II (1971) $580-582$.

21. Matzinger, D. F., E. A. Wernsman, H. F. Ross and J. M. Moseley: Genetic diversity for alkalinity number of water-soluble ash; Tob. Sci. 15 (1971) 152-153.

22. Bowman, D. R., T. C. Tso and J. F. Chaplin: Leaf characteristics of four flue-cured varieties according to stalk position, III: Starch, cellulose, lignin, wax, crude ash, and alkalinity of water-soluble ash; Tob. Sci. 17 (1973) 8-9.

23. Matzinger, D. F, and E. A. Wernsman: Inheritance and relationships among plant characters and smoke constituents in flue-cured tobacco; Fifth International
Tobacco Scientific Congress, Hamburg, 1970, pp. $68-75$.

24. Chaplin, J. F.: Comparison of type 32 and fluecured tobacco cultivars produced under flue-cured cultivation when air- and flue-cured; Tob. Sci. Ig (1975) 120-122.

25. Rathkamp, G., T. C. Tso and D. Hoffmann: Chemical studies on tobacco smoke, XX: Smoke analysis of cigarettes made from bright tobaccos differing in variety and stalk positions; Beitr. Tabakforsh. 7 (1973) 179-189.

26. Tso, T. C., and J. F. Chaplin: Unpublished data.

The author's address:

Tobacco Research Laboratory, Agricultural Research Service, U.S. Dept. of Agriculture, Oxford, N.C., 27565, U.S.A. 